\title{
Possible relations between reproduction of the yellow-necked mouse (Sylvaemus flavicollis) and oak yield
}

\author{
Victoria A. Vekhnik*, Vladimir P. Vekhnik, Olga A. Rozentsvet, \\ Elena S. Bogdanova
}

\begin{abstract}
Some species of mammals can reproduce in anticipation of future food abundance. During 2017-2018 we studied the reproduction of a common abundant species, the yellow-necked mouse Sylvaemus flavicollis, in oak communities to determine if the timing of reproduction has a predictive character during the autumn peak of reproduction. During the maturation of acorns the proportion of females in oestrus gradually decreased along with the share of males with reproductive activity. By the time the acorns were completely ripe and fell, the most of juveniles became independent, and a portion of the young females became sexually mature. In 2018, a high yield oak year, the sexual activity of the males was considerably higher than that in 2017, a moderate yield oak year, what can point on its role in the regulation of the intensity of reproduction. Thus, instead of any prediction, mating and pregnancy in a large proportion of the mice, began at the beginning of acorn ripening, due to females feeding on immature seeds, eliminating a delay between forage yield and rodent reproduction. A possible reason for this synchronization is the contents of triacylglycerols, the main constituents of body fat in animals, in the rodent diet. During the maturation of acorns, its proportion increases considerably, which can increase the survival rate of juveniles.

How to cite this article: Vekhnik V.A., Vekhnik V.P., Rozentsvet O.A., Bogdanova E.S. 2019. Possible relations between reproduction of the yellow-necked mouse (Sylvaemus flavicollis) and oak yield //Russian J. Theriol. Vol.18. No.1. P.33-42. doi: 10.15298/rusjtheriol.18.1.04.
\end{abstract}

KEY WORDS: Sylvaemus flavicollis, reproduction, Quercus robur, Zhiguli Mts., lipids, synchronization.

VictoriaA.Vekhnik [ivavika@rambler.ru], I.I. Sprygin Zhiguli State Nature Biosphere Reserve, Zhigulyovskaya str. 1, Bakhilova Polyana Village, Samara Oblast 445362, Russia; Vladimir P. Vekhnik [vekhnik@mail.ru], I.I. Sprygin Zhiguli State Nature Biosphere Reserve, Zhigulyovskaya str. 1, Bakhilova Polyana Village, Samara Oblast 445362, Russia; Olga A. Rozentsvet [olgarozen55@mail.ru], Institute of Ecology of the Volga River Basin of RAS, Komzina str. 10, Togliatti, Samara Oblast 445003, Russia; Elena S.Bogdanova [cornales@mail.ru], Institute of Ecology of the Volga River Basin of RAS, Komzina str. 10, Togliatti, Samara Oblast 445003, Russia.

\section{Возможная взаимосвязь между размножением желтогорлой мыши (Sylvaemus flavicollis) и плодоношением дуба}

\section{В.А. Вехник, В.П. Вехник, О.А. Розенцвет, Е.С. Богданова}

РЕЗЮМЕ. Некоторые виды млекопитающих могут размножаться в соответствии с будущим обилием пищи. В 2017-2018 годах было исследовано размножение широко распространенного массового вида - желтогорлой мыши Sylvaemus flavicollis - в кверцетальных сообществах в период созревания желудей, чтобы определить, имеет ли периодизация его размножения опережающий характер в течение осеннего пика размножения. В период созревания желудей доля самок в эструсе постепенно уменьшалась, как и доля репродуктивно активных самцов. К моменту полного созревания и опадения желудей значительная часть детенышей становились самостоятельными, многие молодые самки становились половозрелыми. В 2018 году, когда урожайность дуба была высокой, репродуктивная активность самцов была значительно выше, чем в 2017 году, когда урожай желудей был средним, что может указывать на ее роль в регуляции интенсивности размножения. Таким образом, вместо «предсказывания» урожая, спаривание и беременность у значительной части мышей происходили в начале созревания желудей благодаря питанию незрелыми семенами во время беременности и лактации, устраняя задержку между созреванием кормов и появлением потомства. Возможной причиной такой синхронизации является содержание в рационе вида триацилглицеринов- основных составляющих жировых отложений у животных. В период созревания желудей их доля значительно увеличивается, что может повышать выживаемость потомства.

КЛЮЧЕВЫЕ СЛОВА: Sylvaemus flavicollis, размножение, Quercus robur, Жигулевские горы, липиды, синхронизация.

* Corresponding author. 


\section{Introduction}

In ecology, the dependence of the intensity of reproduction on the number of available resources is unquestionable (Odum, 1959; Ricklefs, 1973). The consumers of pulsed resources are often generalists that respond numerically, but with a time lag, to fluctuating resource levels (Ostfeld \& Keesing, 2000). However, in some cases, such a lag can be reduced. Anticipatory reproduction has been found in North American pine squirrel Tamiasciurus hudsonicus, red squirrel Sciurus vulgaris (Boutin et al., 2006, 2013; Wauters et al., 2008), montane vole Microtus montanus (Berger et al., 1981; Sanders et al., 1981), deer mouse Peromyscus maniculatus (Korn, 1988), white-footed mouse Peromyscus leucopus (Marcello et al., 2008), eastern chipmunk Tamias striatus (Bergeron et al., 2011), and red fox Vulpes vulpes (Lindström, 1988). Anticipatory reproduction is the mechanism of population regulation by which an animal gives birth to an adequate number of juveniles before the actual ripening of the yield of its main food source, and the period of maximal abundance of food coincides with the period of independent feeding of juveniles. Wauters et al. (2008) considered that an elimination of the population lag is normally present when resources are produced in pulses. In some cases, anticipatory reproduction was not demonstrated. In a special study of Siberian flying squirrel Pteromys volans, anticipatory reproduction was not found (Selonen et al., 2015). In many cases, the mechanisms of anticipation of food availability are based on abiotic factors such as photoperiod length, precipitation or temperature (Madsen, 1999; Bronson, 2009; Barrett \& Bolborea, 2012).

The purpose of this study was to determine how the periodization of reproduction is related to the maturation of seeds in a common wide-spread species, the yellow-necked mouse Sylvaemus flavicollis (Melchior, 1834). This species is an obligate seed predator, dwelling both in burrows and the hollows of tree trunks, whose main forage is largely acorns (Sablina, 1953; Petrov, 1963; Bergstedt, 1965; Jensen \& Nielsen, 1986; Juškaitis, 2002). General regularities in species reproduction are well known. In the Eastern European part of its range, two peaks of reproduction in the species, which are connected with the productivity of oak, lime or hazel, are observed (Sviridenko, 1951; Adamczewska, 1961; Pucek et al., 1993). In years of poor oak harvests, the autumn peak of reproduction can be absent (Snigirevskaya, 1954; Adamczewska, 1961; Suchomel \& Heroldová, 2008). Stenseth et al. (2002) also found clear density dependence from seed crops of the previous year both during the summer and the winter.

Snigirevskaya (1954) studied the reproduction and nutrition of the species in the Zhiguli State Nature Reserve in 1941, 1949 and 1950 years. Detailed analysis of 126 stomachs showed that seeds are the main forage of the mouse from May till September. Stocks of mice included always both acorns and lime seeds. Autumn peak depends on the presence of available seeds. In the Zhiguli Nature Reserve lime seeds mature a month or two later than acorns. The spring peak of reproduction depends here on the storages of lime seeds from previous year.

We studied the reproduction of the yellow-necked mouse during the period of acorn maturation in summer. Previously we found that another species of the same oak community, the edible Glis glis, starts reproduction long before the maturation of acorns, showing the pattern similar with anticipatory reproduction (Vekhnik, 2019). But the juveniles of both species usually were trapped simultaneously (unpublished data). So, according to the finding by Pucek et al. (1993) that the rodent reaches its highest abundances in autumn of the years following mast peaks, the initial hypothesis was that due to the short period of pregnancy and lactation, during the autumn peak in reproduction, the yellow-necked mouse begin reproduction exactly in the period of plentiful acorn harvest. Also we analysed the lipid components of acorns, the main forage of the yellow-necked mouse during summer period. Lipids are one of the indicators of the nutritional value of forages and represent a kind of energy and metabolic stock of cells.

\section{Material and methods}

\section{The study area}

The studies were conducted in the I.I. Sprygin Zhiguli State Nature Biosphere Reserve (Samara Oblast, Russia) located between $53^{\circ} 20^{\prime} 00^{\prime \prime}$ and $53^{\circ} 27^{\prime} 30^{\prime \prime} \mathrm{N}$ and $49^{\circ} 34^{\prime} 00^{\prime \prime}$ and $50^{\circ} 00^{\prime} 12^{\prime \prime} \mathrm{E}$. Most of the Reserve lies in the Zhiguli Mountains, where the maximum elevation is $381.2 \mathrm{~m}$. The climate is temperate continental with frosty winters and warm summers. The dominant composition is a lime tree Tilia cordata and oak Quercus robur forest with a mixture of maple Acer platanoides, ash Fraxinus excelsior, and areas of maple and lime forest mixed with aspen Populus tremula. In the understory of the Zhiguli forests, the most common species are hazel Corylus avellana, spindle tree Euonymus verrucosus and fly honeysuckle Lonicera xylosteum.

\section{Fructification of trees}

During 2017-2018, the evaluation of the productivity of oak as a main source of forage and hazel as alternative source of forage was conducted visually using the 6-point scale of Kapper-Formozov, where " 0 " indicated crop failure and " 5 " indicated very abundant fruiting.

We established 10 cones of $1 \mathrm{~m}^{3}$ square each for collecting acorns and hazelnuts. The total mass and number of seeds were counted.

The acorn ripening period was tracked. Once every 10 days from the beginning of the formation of seeds until they fell, we collected 15 acorns from fixed places. The acorns were weighed, and the average mass was measured.

\section{Analysis of the lipid classes and fatty acid com- position}

We took by one sample of acorns, collected from different trees at the beginning of July and at the end of 
August (in total four samples by 2.3-2.8 grams) for the analysis of lipids to track changes during the maturation of the seeds. The lipids were extracted three times by a chloroform-methanol mixture $(1: 2, \mathrm{v} / \mathrm{v})$ with the simultaneous mechanical destruction of the tissues (Kates, 1972). The lipids were separated by thin-layer chromatography as described earlier (Rozentsvet et al., 2014).

Neutral lipids (NLs) were separated by TLC on $10 \times 10$ $\mathrm{cm}$ one-dimensional silica gel plates (Haapsalu) with double development, first with toluene:hexane:formic acid $(140: 60: 1, \mathrm{v} / \mathrm{v} / \mathrm{v})$ for the whole plate height followed by hexane:diethyl ether:formic acid $(60: 40: 1, \mathrm{v} / \mathrm{v} / \mathrm{v})$. Tripalmitate, oleic acid, and n-heptanol (Sigma-Aldrich) were used as standards. The lipids were visualized using $10 \% \mathrm{H}_{2} \mathrm{SO}_{4}$ in methanol followed by heating for $15 \mathrm{~min}$ at $180{ }^{\circ} \mathrm{C}$. The NLs were quantified using a spectrophotometer PE-3000 UV (Russia). Tripalmitate was used as a calibration standard.

Fatty acids (FA) were analysed in the form of their methyl esters (FAMEs), which were obtained by boiling the lipids in 5\% hydrochloric acid in methanol for $1 \mathrm{~h}$. The esters were purified by preparative TLC and analysed using a Crystal 5000.1 gas-liquid chromatography system (Crystal 5000.1, Chromatek, Yoshkar-Ola, Russia). The separation of the esters was conducted using an isothermal regime with a RESTEK capillary column $(105 \mathrm{~mm} \times 0.25 \mathrm{~mm})$. The temperatures of the column and detector were 180 and $260^{\circ} \mathrm{C}$, respectively. The flow rate of the carrier gas (helium) was $2 \mathrm{ml} / \mathrm{min}^{-1}$. The FAMEs were identified by comparing their retention times with FA standards (Supelco 37, Supelco, USA), and quantification was performed using an internal standard of heptadecanoate.

\section{Trapping}

The censuses of the mice were conducted from the beginning of the growth of acorns until the end of warm weather suitable for the censuses: from July 4 until August 20, 2017 and from June 29 until August 20, 2018. The captures were conducted daily and interrupted only on rainy days. The overall number of census days in 2017 was 32, and in 2018, it was 38 .

We caught animals in metal-spring live traps with trap doors, which were hung on tree trunks in two lines of 25 traps at a height of 1.5-2 $\mathrm{m}$ and approximately 10 $\mathrm{m}$ apart. Bread fried in sunflower seed oil was used as bait. The traps were checked once per day in the morning.

All of the trapped animals were weighed after every capture by an Emerald JE250 hand-held jewellery scale (Ohaus Corporation, USA). The age and sex were determined. Two age categories of animals were conventionally identified: young with a body mass of approximately $25 \mathrm{~g}$ and less and adults. Initially, in 2017, non-individual marking of all the captured animals was conducted by a solution of a brilliant green dye. In 2018, individual marking was applied using bird rings (Benelux, Belgium) with a diameter of $4 \mathrm{~mm}$. The rings of different color with numbers were fixed on a hind paw. In the case of loss the data were not taken into account.
The reproductive state of the mice was determined visually. Females with an open vagina were considered to be in oestrus (Stockard \& Papanicolaou, 1917). If the vagina was closed, the females were considered inactive, while some of these females could be pregnant. Females with mucus plugs were considered to be in oestrus. At external examination, the males with significantly enlarged testicles were considered reproductively active.

\section{Statistical analysis}

To determine the necessary tests, the data were checked for normality by Kolmogorov-Smirnov and Lilliefors tests. For the data that did not fit the normal distribution median, the minimum and maximum were given. The significance of pairwise comparisons of number of animals in different reproductive state as well as the differences in lipid composition in months were tested by a chi-square test $\left(\chi^{2}\right)$ with Yates-correction. To analyse the dependence of the onset of oestrus from body mass in the young females, a logistic regression model was used. To test for the effects of the average mass of the acorns on the share of lactating females and active males, a Spearman's rank correlation coefficient $\left(\mathrm{r}_{\mathrm{s}}\right)$ was used. The statistical analysis was performed using Statistica 13.0 for Windows.

\section{Results}

\section{Yield of the tree species}

In 2017, the oak yield was medium: 3 points on the Kapper-Formozov scale. Fruiting was more abundant on the edges and on individual trees than in the depths of the forest. The yield of hazel was typically lower: 2 points on the Kapper-Formozov scale. Hazel was also only fruiting on the edges. We collected $638.7 \mathrm{~g}$ (189 seeds) of acorns. It was not possible to evaluate the mass of the hazel nuts because the scarce nuts that fell had already been chewed by rodents.

In 2018 , the yield of oak was maximal ( 5 points), and the yield of hazel was minimal - only 1 point. Several nuts were found only on separate bushes on the edges. We collected $5123.51 \mathrm{~g}$ of acorns (1603 seeds). The shells of the hazelnuts were almost absent in the cones.

In 2017, the dynamics of acorn ripening were measured from July 4 to August 23. In 2018, the observation period started earlier because of weather conditions: from June 29 to August 18. The total tracked growth duration in both years was 51 days (Fig. 1).

\section{Lipid composition of acorns}

At the beginning of ripening, the content of neutral lipids in the acorns was quite high (Table 1). The content of sterols in the initial period amounted to $30-32 \%$ of the total content of neutral lipids. The content of triacylglycerols in July was $21.8 \%$.

The picture changed significantly when the fruits ripened. In August, the total lipid content increased a bit $\left(\chi^{2}=9.4, p=0.02\right)$, but the proportion of triacylglycerols increased to $66.7 \%\left(\chi^{2}=28.41, p<0.001\right)$. In mature 

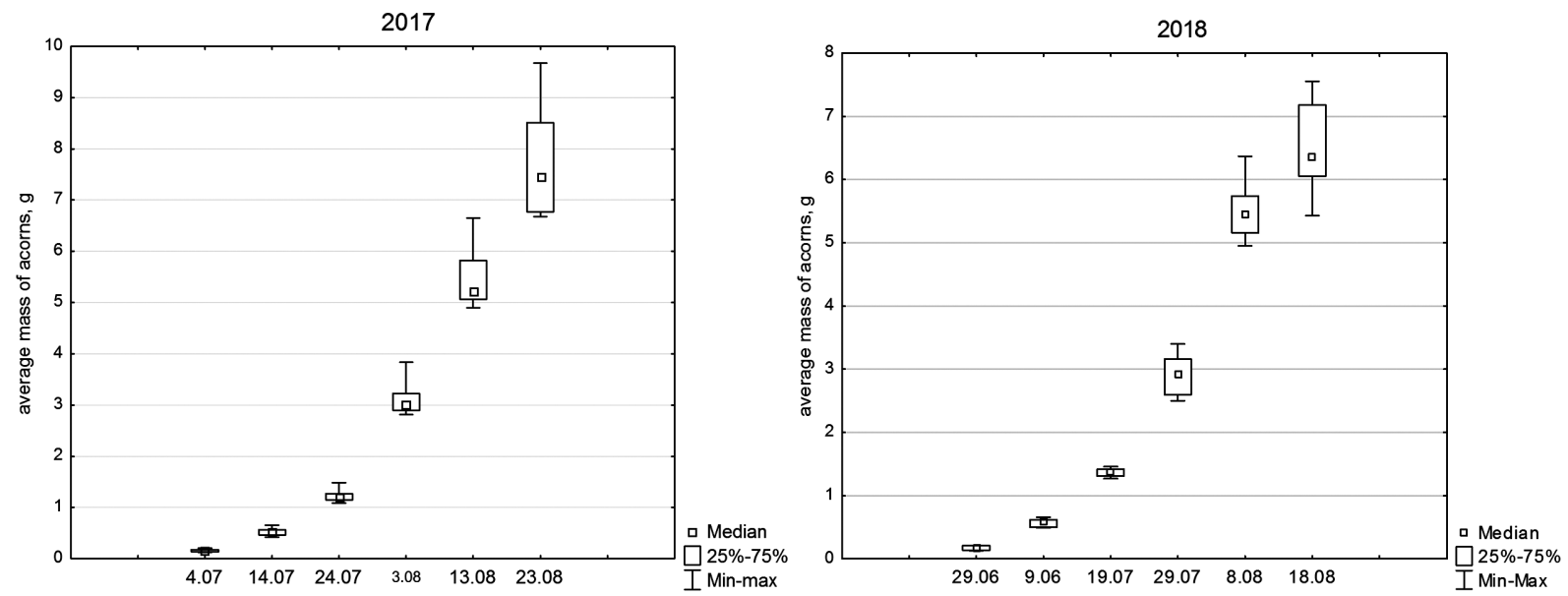

Fig. 1. Dynamics of the mass (g) of acorns in the stationary plots in the Zhiguli Mts. in 2017-2018.

Table 1. Content of neutral lipids, sterols and triacylglycerols in acorns

\begin{tabular}{|c|c|c|}
\hline \multirow{2}{*}{ Lipid components } & \multicolumn{2}{|c|}{ Content, mg/g of wet weight } \\
\cline { 2 - 3 } & July & August \\
\hline Neutral lipids & $1.1 \pm 0.1$ & $1.36 \pm 0.3$ \\
\hline Sterols & $0.24 \pm 0.2$ & $0.16 \pm 0.1$ \\
\hline Triacylglycerols & $0.36 \pm 0.15$ & $0.91 \pm 0.2$ \\
\hline
\end{tabular}

acorns, the content of sterols decreased and amounted to $11.8 \%$ of the sum of the neutral lipids $\left(\chi^{2}=1.23, p=0.27\right)$.

The data in Table 2 show that 15 acids with a chain length of 12 to 24 carbon atoms were found in the fatty acid composition of the studied fruits. The main fatty acids were palmitic (C 16:0), oleic (C 18:1), linoleic (C 18:2) and linolenic (C 18:3) acids. The acid C 18:3 prevailed in July.

In August, similarly to the neutral lipids, the composition of fatty acids changed. The content of C 18:1 acid increased $\left(\chi^{2}=281.8, p<0.001\right)$, while the content of
C 18:3 acid decreased $\left(\chi^{2}=633.73, p<0.001\right)$. Linoleic acid (C 18:2) remained predominant.

\section{Data from the censuses of yellow-necked mice}

In 2017, a total of 176 mice were caught. The number of recaptures was 219 . Relative abundance was 11 individuals per 100 trap nights. In 2018, 140 mice were trapped. The number of recaptures was 332. Relative abundance was 7.4 individuals per 100 trap nights. Each animal was re-trapped from 0 to 12 times per active season.

Table 2. Composition of fatty acids in the total lipids of acorns ( $\%$ from the sum of the acids).

\begin{tabular}{|c|c|c|}
\hline Acid & July & August \\
\hline C $12: 0$ & 0.1 & 0.21 \\
\hline C $14: 0$ & 0.36 & 0.77 \\
\hline C $16: 0$ & 23.8 & 25.52 \\
\hline C $16: 1$ & 0.56 & 0.86 \\
\hline C $17: 0$ & 0.27 & 0.18 \\
\hline C $18: 0$ & 1.14 & 2.37 \\
\hline C $18: 1 n-9$ & 2.7 & 12.10 \\
\hline C $18: 1 \mathrm{n}-7$ & 0.46 & 3.96 \\
\hline C $18: 3 n-6$ & 45.45 & 43.19 \\
\hline C $20: 0$ & 21.32 & 8.61 \\
\hline C $20: 1$ & 0.90 & 0.91 \\
\hline C $22: 0$ & 0.13 & 0 \\
\hline C $23: 0$ & 1.75 & 0.72 \\
\hline C $24: 0$ & 0.14 & 0.22 \\
\hline
\end{tabular}




\section{The intensity of reproduction in females}

In 2017, at the very beginning of acorn growth at the beginning of July, oestrus was observed in most of the females, and no pregnant females were found (Fig. 2). The remaining females were nursing. During the maturation of acorns in the second ten-day period of June, the proportion of females in oestrus gradually decreased, and the number of inactive, presumably pregnant females increased. In the third ten-day period of July and in both such periods of August, the adult females were either inactive or lactating, and females in oestrus were not found. The young females were in oestrus or inactive.

In 2018, at the beginning of the studied period, the share of adult females in oestrus was a bit lower than that in 2017 (at the beginning of acorns maturation $\chi^{2}$ $=0.46, p=0.5)$. In the third ten-day period of July, the females in oestrus disappeared, similarly to the previous year. The share of lactating females was higher during all the periods of capture, excluding the second ten-day period of July (for the first ten-day period $\chi^{2}=0.46, p=$ 0.6 ; for the second ten-days period $\chi^{2}=0, p=1.0$, for the fourth ten-days period $\chi^{2}=0, p=1.95$ ), and in August, only lactating females were trapped. Among the young females, the share of individuals in oestrus was higher than that in 2017. In young males, reproductive activity was not observed.

In young females we found a dependence of the onset of the oestrus period on body mass indicating their age, which was confirmed by logistic regression, in $2017 \chi^{2}$ $=13.65, p<0.001$, and $n=82$ and $\chi^{2}=7.24, p=0.007$, and $n=61$ in 2018 (Fig. 3).

We found the correlation between the average mass of acorns (medians were used) during ripening and the
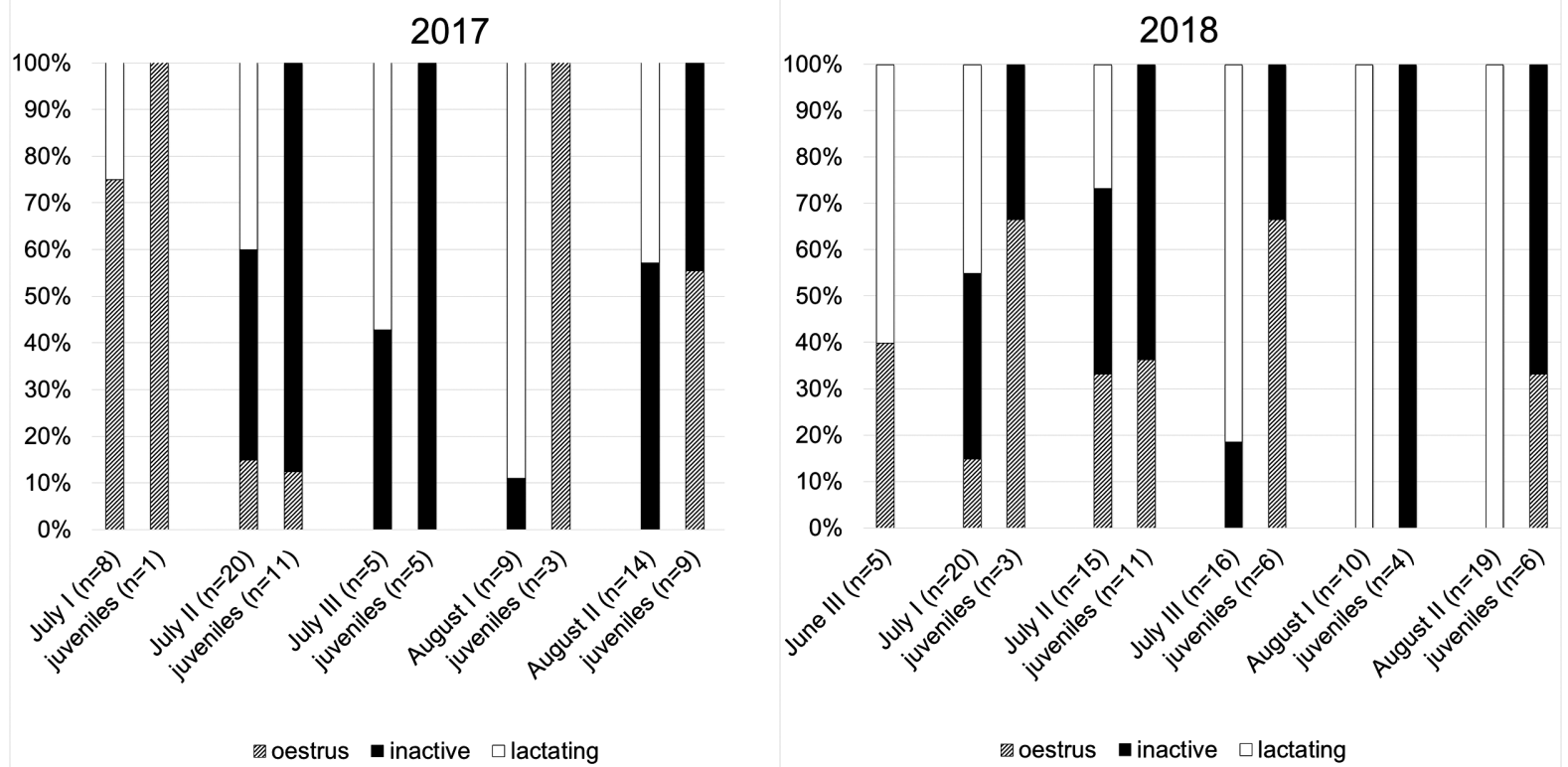

Fig. 2. Reproductive activity of yellow-necked mouse females in the Zhiguli Mts. during the maturation of acorns in 2017-2018.
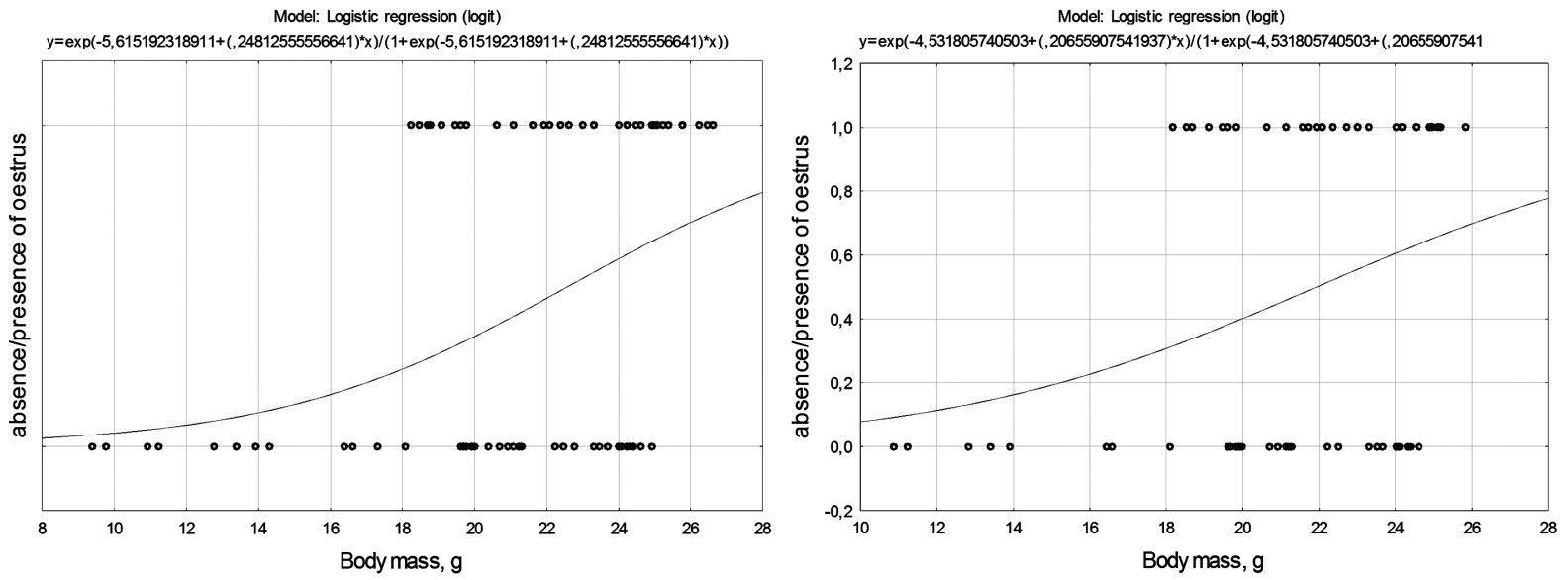

Fig. 3. Dependency of the onset of oestrus from the body mass of young females in 2017-2018 (a logistic regression model). 

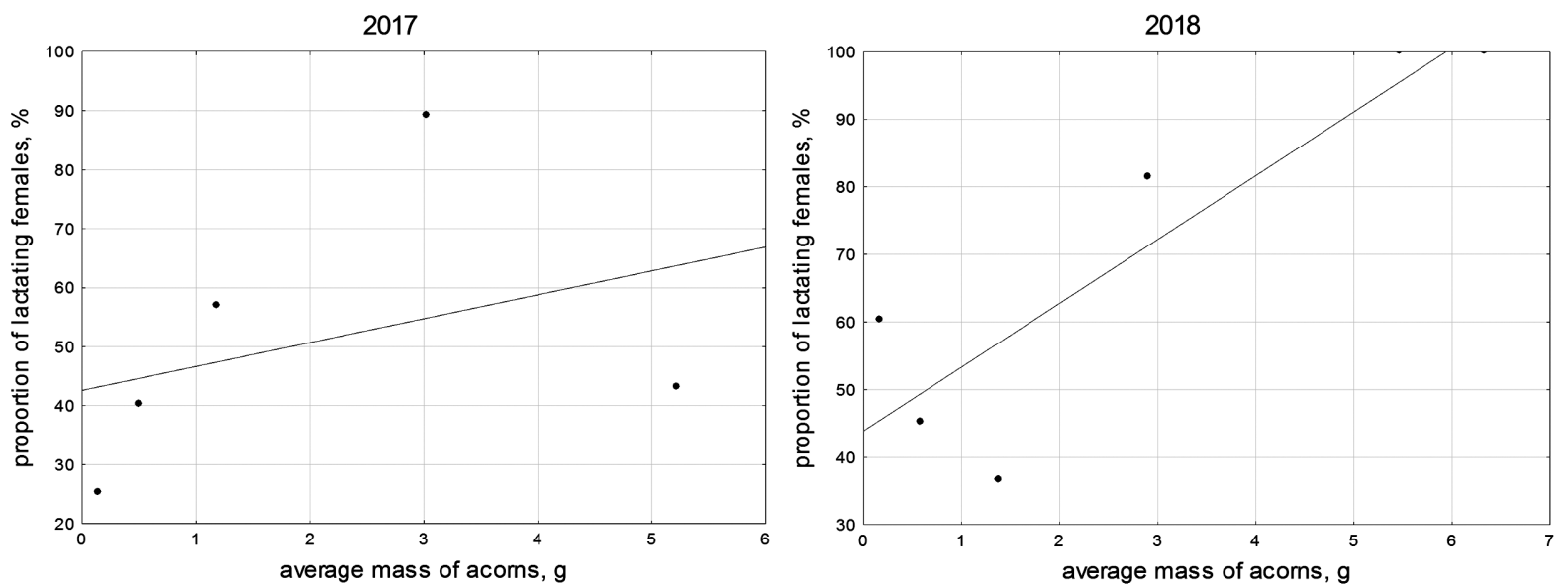

Fig. 4. The dependence of the proportion of lactating females from the average mass of ripening acorns.

proportion of lactating females. In 2017, $\mathrm{r}_{\mathrm{s}}=0.7(n=5)$, and in 2018, $\mathrm{r}_{\mathrm{s}}=0.75(n=6)$ (Fig. 4).

\section{The intensity of reproduction in males}

In both years throughout the census period, active males were trapped (Fig. 5). The share of males with reproductive activity gradually decreased during the census. In 2017, a slight increase was observed in the second ten-day period of August.

In 2018 , the sexual activity of the males was higher than that in 2017 both at the first $\left(\chi^{2}=1.07, p=0.3\right)$ and the second decade $\left(\chi^{2}=7.58, p<0.001\right)$ from the beginning of census. The decrease in the number of active males during the observation period was more abrupt.

We found the correlation between the average mass of acorns (medians were used) during ripening and the proportion of active males. In 2017, $\mathrm{r}_{\mathrm{s}}=-0.9(n=5)$, and in 2018, $r_{s}=-0.94(n=6)$ (Fig. 6).

\section{Discussion}

\section{Yield of the tree species}

Changes in the oak yields showed the "pulsating character" of the fructification of oak. Food conditions during two years of study were different, causing differences in the intensity of reproduction.

As fructification of hazel nuts acorns was very low during both years, it could not influence on the mice reproduction. Snigirevskaya (1954) also recorded the low productivity of hazel in 1941, 1949 and 1950.

\section{Lipid composition and its possible consequences}

Changes in the composition and content of lipids during maturation of the main forage could be one of reasons for the timing of reproduction in the yellow-necked mouse. The sufficient content of neutral lipids in immature acorns, not substantially lower than that in mature
2017

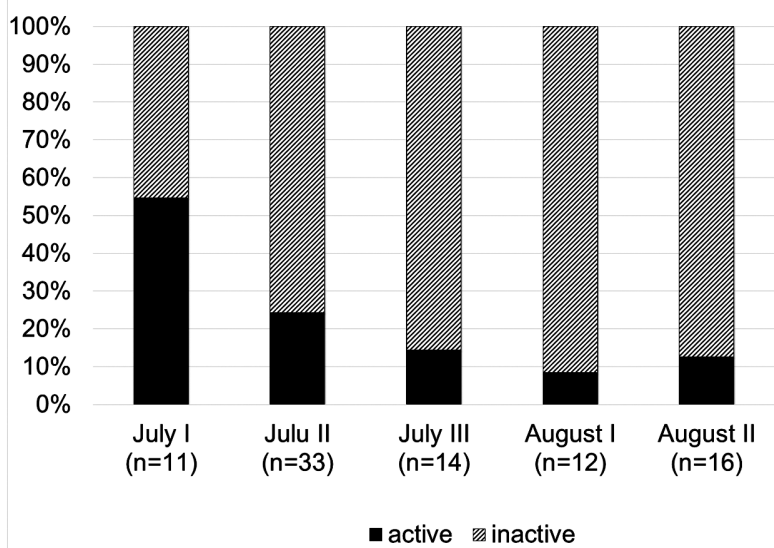

2018

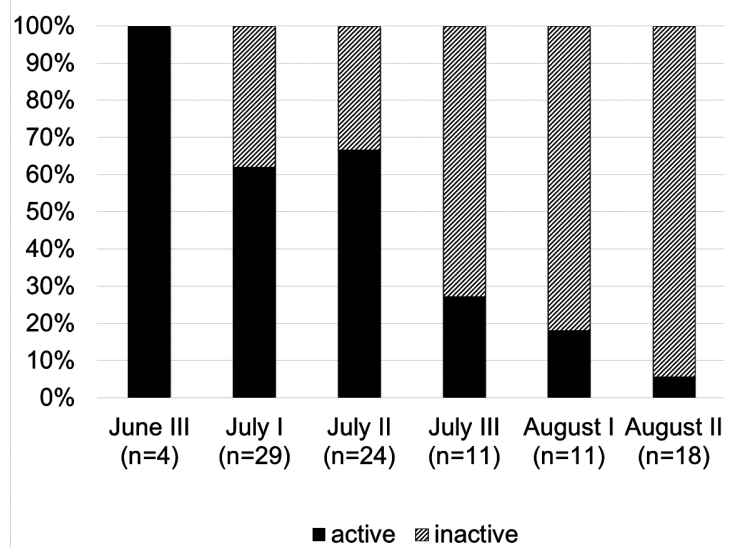

Fig. 5. Reproductive activity of yellow-necked mouse males in the Zhiguli Mts. during the maturation of acorns in 2017. 
2017

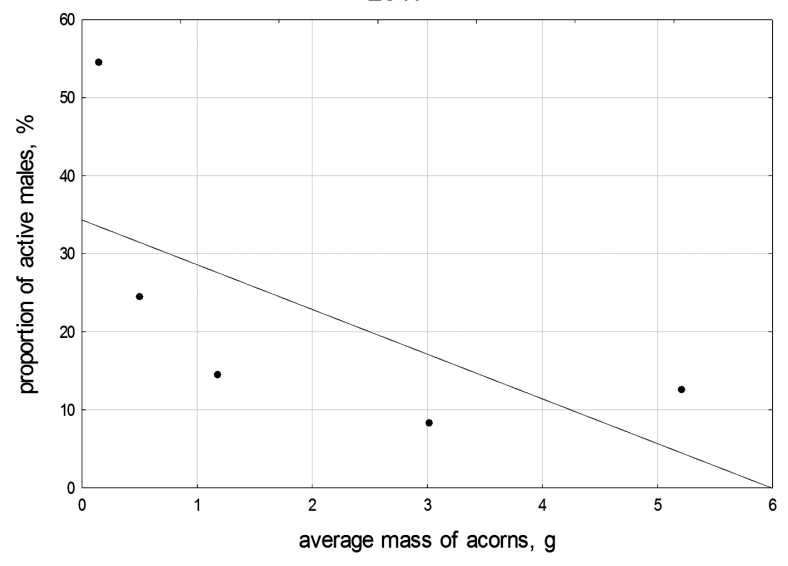

2018

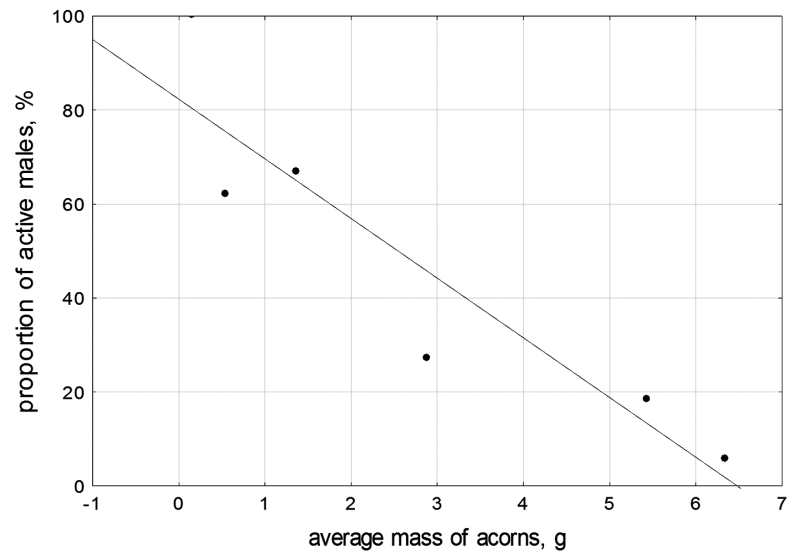

Fig. 6. The dependence of the proportion of active males from the average mass of ripening acorns.

seeds, could maintain the successful course of pregnancy. A high proportion of triacylglycerols in mature seeds could allow for the successful wintering of juveniles and the survival of females after the lactation period. Triacylglycerols are the main constituents of body fat in animals (Nelson \& Cox, 2000).

Additionally, a decrease in the content of sterols in acorns could contribute to the lower reproductive activity of males in August despite the abundance of food because plant sterols structurally cognate with the steroid hormones of animals (Benveniste, 2004).

\section{Data from the censuses}

A comparison of the total number of trapped animals with the results of previous rodent censuses (unpublished data) indicates that 2017 was a year of high abundance for the yellow-necked mouse and 2018 was a year of moderate abundance. A significant number of repeated catches indicated a small amount of migratory activity in the mice, which makes it possible to adequately assess the dynamics of the reproductive period. The total number of captured animals using individual and non-individual marking gave comparable results.

\section{Intensity of reproduction in females}

The results of the census showed that in a significant portion of the population, the period of the census during the ripening of the acorns included the whole breeding cycle, from the mating of adult females to the reaching of puberty by their juveniles. For polyoestrous species, the maximal proportion of females in oestrus at the beginning of census was sufficient to detect the beginning of mass reproduction in both years coinciding with the early period of the ripening of acorns. Lipid components of immature acorns could be enough for successful pregnancies.

The analysis of body mass of young females showed that oestrus begins depending of their age despite feeding conditions. So, to the acorn fell the large part of young females become mature.
Probably, a higher number of dry females in 2017 or a shorter period of reproduction with lower acorn yield might cause the difference in the number of lactating females in two years. The decrease in the number of lactating females in the second period of August in 2017 was most likely connected with the termination of lactation. The intravital definition does not allow us to make an exact conclusion, but changes in the intensity of reproduction in the two years are clear.

It should be noted that in yellow-necked mice, a polyoestrous species, it is not possible to find synchronous reproduction in the entire population; it is only possible to address the peaks of reproduction. Throughout the periods of capture, lactating mice were found. This is due to both the presence of two peaks of reproduction in a year and the participation of individuals of different age groups in reproduction.

\section{Intensity of reproduction in males}

The maximal proportion of active males was observed at the beginning of the census, i.e., the maximal intensity of pairings occurred at the beginning of acorn maturation in both years. This pattern is similar with females, whose maximal intensity of oestrus was observed also at the beginning of the census period.

It was also similar to the mechanism of regulation of reproduction of dormice in the optimum range, where the period of sexual activity coincides with the flowering of beech, the main forage of dormice, before the ripening of the seeds (Bieber, 1998; Schlund et al., 2002; Fietz et al., 2005). However, in the dormouse, the reproductive period is much more synchronous and "stretched" than that of the yellow-necked mouse because of longer periods of pregnancy and lactation. In the optimum range, the dormouse relies on the abundance of buds and beech ovaries, while the beginning of reproduction of the mouse occurs at the onset of acorn growth a month and a half after flowering.

The reproductive activity of the males was much lower in 2017 than in 2018, when the share of active 
males rose to $100 \%$ at the beginning of acorn maturation, although the proportion of active males could be underestimated at visual determination, showing probable role of male activity in reproductive regulation in mast and non-mast years. It is likely that the lower proportion of lactating females in August 2017 could be a consequence of the reduced reproductive activity of the males, especially considering that multiple paternities is common in the yellow-necked mouse (Gryczyńska-Siemiątkowska et al., 2008).

The dependence of the reproductive activity of males on food conditions in different years is not similar to the reproductive activity of females, which is only the function of body mass connected with age. Another difference between the reproductive activity of males and females is that females mature earlier than males. We never found active males in the last generation of juveniles. Adamczewska (1961) also found that in Białowieża National Park, in males that were born at the beginning of the breeding season, spermatogenesis took place normally, but if they were born at the end phase of the breeding season, the animals did not mature.

Other works on the reproduction of the yellow-necked mouse indirectly confirm the role of the sexual activity of males in reproductive regulation. Therefore, in Białowieża forest, in years of low reproduction, the number of males with enlarged testes was very small (Adamczewska, 1961). Nurullina (1957) observed the complete termination of spermatogenesis at the end of August in non-mast years. In a mast year, spermatogenesis lasted until October.

\section{Reproduction of mice and the fructification of oak}

Our data show that at the beginning of their maturation, reproduction at the end of summer is synchronized with the onset of the maturation of acorns. This was confirmed by the maximum proportion of males with visible manifestations of reproductive activity and oestrus in a significant proportion of the females at the beginning of the census period. The pregnancy of a significant portion of females occurred during the ripening of acorns. By the time the acorns fell, many of the young had become sexually mature and accumulated supplies for future wintering.

Laboratory studies have shown that rodents spend more energy during lactation than during pregnancy (Dial \& Avery, 1991; Nutrient Requirements..., 1995). This allows females to successfully breed offspring at the very beginning of the ripening of the main forage with a relatively smaller amount of food in the biotopes. Thus, the females feed their young on the basis of the nutrition contained in immature seeds, and independent juveniles abundantly feed on mature seeds. Snigirevskaya (1954) also wrote that "the mice start foraging by the seeds of new crop far before their ripening." Analysis of lipid composition also showed that immature acorns include enough quantity of necessary lipids.

Our results support the findings of White (2013) that the consumption of immature seeds is necessary for pregnant females to obtain nutrients until the full ripening of the main forage. He showed that substances contained only in immature seeds are necessary for the successful breeding of juveniles (White, 2011). In this work, the author cites the experimental work of Wereszczynska et al. (2007), who reported that mature acorns are not enough for the successful reproduction of the bank vole, Clethrionomys glareolus. The dependence of reproduction on the abundance of milk-ripe seeds was confirmed for the house mouse (Bomford, 1987). American squirrels also begin to eat seeds at the very beginning of their formation (Koprowski, 1991). The same dependency was found for the edible dormouse in the eastern periphery of the range (Vekhnik, 2010, 2019).

Then, the maximum survival of offspring is provided, which White (2008) considers the "Achilles heel" in the existence of populations. Other reproductive advantages have been observed with this synchronization (Hämäläinen et al., 2017). Bergstedt (1965) found a correlation between the amount of food and over-wintering mortality in yellow-necked mice.

Using the example of the yellow-necked mouse, it can be seen that such synchronization, similar to anticipatory reproduction by timing, is not an obligatory feature of the biology of a particular species. In winter, the reproduction of mice can occur due to the remaining stocks of seeds (Snigirevskaya, 1954). In other species, litters can be produced in anticipation or reproduction can begin after a plentiful harvest of the main forage. Therefore, the North American pine squirrel Tamiasciurus hudsonicus (Williams et al., 2014), and the red squirrel Sciurus vulgaris (Wauters et al., 2008), can also have two litters per year, and during the spring peak, reproduction depends on the harvest of cones from the previous year.

Thus, in the case of the yellow-necked mouse, we observed the absence of a delay between mast seeding and the birth of juveniles due to the consumption of unripe seeds. According to the results, the mechanism of regulation of reproduction in the studied species does not appear to be "predictive" of the future crop according to environmental triggers. It is instead characterized by the dependence of fertility on the current abundance of immature seeds, the consequence of which is the maximum availability of ripened forage for the offspring that are becoming independent.

ACKNOWLEDGEMENTS. This study was supported by RFBR and Samara Oblast (research project No.17-44-630288).

\section{References}

Adamczewska K.A. 1961. Intensity of reproduction of the Apodemus flavicollis (Melchior, 1834) during the period 1954-1959 // Acta Theriologica. Vol.5. P.1-21.

Barrett P. \& Bolborea M. 2012. Molecular pathways involved in seasonal body weight and reproductive responses governed by melatonin // Journal of Pineal Research. Vol.52. P.376-388. 
Benveniste P. 2004. Biosynthesis and accumulation of sterols // Annual Review of Plant Biology. Vol.55. P.429-457.

Berger P.J., Negus N.C., Sanders E.H. \& Gardner P.D. 1981. Chemical triggering of reproduction in Microtus montanus // Science. Vol.214. P.69-70.

Bergeron P., Réale D., Humphries M.M. \& Garant D. 2011. Anticipation and tracking of pulsed resources drive population dynamics in eastern chipmunks // Ecology. Vol.92. P.2027-2034.

Bergstedt B. 1965. Distribution, reproduction, growth and dynamics of the rodent species Clethrionomys glareolus (Shreber), Apodemus flavicollis (Melchior) and Apodemus sylvaticus (Linné) in Southern Sweden // Oikos. Vol.16. P.132-160.

Bieber C. 1998. Population dynamics, sexual activity and reproduction failure in the fat dormouse (Myoxus glis) // Journal of Zoology. Vol.244. P.223-229.

Bomford M. 1987. Food and reproduction of wild housemice. I. Diet and breeding seasons in various habitats on irrigated cereal farms in New South Wales // Australian Wildlife Research. Vol.14. P.183-196.

Boutin S., McAdam A.G. \& Humphries M.M. 2013. Anticipatory reproduction in squirrels can succeed in the absence of extra food // New Zealand Journal of Zoology. Vol.40. P.337-339.

Boutin S., Wauters L.A., McAdam A.G., Humphries M.M., Tosi G. \& Dhondt A.A. 2006. Anticipatory reproduction and population growth in seed predators // Science. Vol.314. P.1928-1930.

Bronson F.H. 2009. Climate change and seasonal reproduction in mammals // Philosophical Transactions of the Royal Society, Biological Sciences. Vol.364. P.3331-3340.

Dial J. \& Avery D. 1991. The effects of pregnancy and lactation on dietary self-selection in the rat // Physiology and Behavior. Vol.49. P.811-813.

Fietz J., Pflug M., Schlund W. \& Tataruch F. 2005. Influences of the feeding ecology on body mass and possible implications for reproduction in the edible dormouse (Glis glis) // Journal of Comparative Physiology. Vol.175. P.45-55.

Gryczyńska-Siemiątkowska A., Gortat T., Kozakiewicz A., Rutkowski R., Pomorski J. \& Kozakiewicz M. 2008. Multiple paternity in a wild population of the yellow-necked mouse Apodemus flavicollis // Acta Theriologica. Vol.53. P.251-258.

Hämäläinen A., McAdam A.G., Dantzer B., Lane J.E., Haines J.A., Humphries M.M. \& Boutin S. 2017. Fitness consequences of peak reproductive effort in a resource pulse system // Scientific Report. Vol.7.P. 9335.

Jensen T.S. \& Nielsen O.F. 1986. Rodents as seed dispersers in a heath - oak wood succession // Oecologia. Vol.70. P.214-221

Juškaitis R. 2002. Spatial distribution of the yellow-necked mouse (Apodemus flavicollis) in large forest areas and it relation with seed crop of forest trees // Mammalian Biology. Vol.67. P.206-211.

Kates M. 1972. Techniques of Lipidology. Second edn. Amsterdam: Elsevier. 342 p.

Koprowski J.L. 1991. Response of fox squirrels and gray squirrels to a late-spring early-summer food shortage // Journal of Mammalogy. Vol.72. P.367-372.

Korn H. 1988. A feeding experiment with 6-methoxybenzoxazollnone and a wild population of the deer mouse
(Peromyscus maniculatus) // Canadian Journal of Zoology. Vol.67. P.2220-2223.

Lindström E. 1988. Reproductive effort in the red fox, Vulpes vulpes, and future supply of a fluctuating prey // Oikos. Vol.52. P.115-119.

Madsen T., Ujvari B., Shine R. \& Olsson M. 2006. Rain, rats and pythons: climate-driven population dynamics of predators and prey in tropical Australia // Austral Ecology. Vol.31. P.30-37.

Marcello G.J., Wilder S.M. \& Meikle D.B. 2008. Population dynamics of a generalist rodent in relation to variability in pulsed food resources in a fragmented landscape // Journal of Animal Ecology. Vol.77. P.41-46.

Nelson D.L. \& Cox M.M. 2000. Lehninger Principles of Biochemistry. Third edn. New York: Worth Publishing. 1152 p.

Nurullina A.N. 1957. [Seasonal cycle of reproduction of the yellow-necked mouse and the bank vole in oak forests of Balashovskaya Oblast] // Trudy Instituta Lesa. Vol.35. P.122-136 [in Russian].

Nutrient Requirements of Laboratory Animals. 1995. Fourth revised edn. Washington: National Academies Press. 192 p.

Odum E.P. 1959. Fundamentals of Ecology. Second edn. Philadelphia: Saunders. 598 p.

Ostfeld R.S. \& Keesing F. 2000. Pulsed resources and community dynamics of consumers in terrestrial ecosystems // Tree. Vol.15. P.232-237.

Petrov O.V. 1963. [Nutrition of mouse-like rodents of forest-steppe oakeries under laboratory conditions] // Voprosy Ekologii i Biocenologii. Vol.8. P.119-173 [in Russian].

Pucek Z., Jędrzejewski W., Jędrzejewska B. \& Pucek M. 1993. Rodent population dynamics in a primeval deciduous forest (Białowieża National Park) in relation to weather, seed crop and predation // Acta Theriologica. Vol.38. P.199-232.

Ricklefs R.E. 1973. Ecology. Newton, MA: Chiron Press. 861 p.

Rozentsvet O., Nesterov V. \& Bogdanova E. 2014. Membrane-forming lipids of wild halophytes growing under the conditions of Prieltonie of South Russia // Phytochemistry. Vol.105. P.37-42.

Sablina T.B. 1953. [The ecology of the yellow-necked mouse in the reserve "Belovezhskaya Puscha"] // Trudy Instituta Morphologii Zhivotnykh imeni A.N. Severtsova. Vol.9. P.231-249 [in Russian].

Sanders E.H., Gardner P.D., Berger P.J. \& Negus N.C. 1981. 6-Methoxybenzoxazolinone: a plant derivate that stimulates reproduction in Microtus montanus // Science. Vol.214. P.67-69.

Schlund W., Scharfe F. \& Ganzhorn J.U. 2002. Longterm comparison of food availability and reproduction in the edible dormouse (Glis glis) // Mammalian Biology. Vol.67. P.219-232.

Selonen V., Varjonen R. \& Korpimäki E. 2015. Immediate or lagged responses of a red squirrel population to pulsed resources // Oecologia. Vol.177. P.401-411.

Snigirevskaya E.M. 1954. [Ecology and economic importance of murine rodents in broad-leaved forests of the Zhiguli Elevation]. PhD Thesis, Leningrad State University, Leningrad. 153 p. [in Russian].

Stenseth N.C., Viljugrein H., Jêdrzejewski W., Mysterud A. \& Pucek Z. 2002. Population dynamics of Clethrionomys glareolus and Apodemus flavicollis: seasonal components 
of density dependence and density independence // Acta Theriologica. Vol.47. P.39-67.

Stockard C.R. \& Papanicolaou G.N. 1917. A rhythmical "heat period" in the guinea pig // Science. Vol.46. P.42-44.

Suchomel J. \& Heroldová M. 2008. Effect of seed crop of trees on the abundance and body parameters of granivorous mammals in isolated forest stands of Southern Moravia (Czech Republic) // Polish Journal of Ecology. Vol.56. P.181-186.

Sviridenko P.A. 1951. [Reproduction and abundance dynamics of the yellow-necked mouse (Apodemus flavicollis Melch.)] // Trudy Instituta Zoologii Akademii Nauk Ukrainskoi SSR. Vol.6. P.46-77 [in Russian]

Vekhnik V.A. 2010. Mass resorption as a mechanism of self-regulation of the edible dormouse (Glis glis L., 1766) reproduction cycle at the periphery of the range // Doklady Biological Sciences. Vol.435. P.415-417.

Vekhnik V.A. 2019. Effect of food availability on the reproduction in edible dormice (Glis glis L., 1766) on the eastern periphery of the range // Mammal Research. https://doi. org/10.1007/s13364-019-00425-6.

Wauters L.A., Githiru M., Bertolino S., Molinari A., Tosi G. \& Lens L. 2008. Demography of alpine red squirrel populations in relation to fluctuations in seed crop size // Ecography. Vol.31. P.104-114.

Wereszczynska A.M., Nowakowski W.K., Nowakowski J.K. \& Jedrzejewska B. 2007. Is food quality responsible for the cold-season decline in bank vole density? Laboratory experiment with herb and acorn diets // Folia Zoologica. Vol.56. P.23-32.

White T.C.R. 2008. The role of food, weather and climate in limiting the abundance of animals // Biological Reviews. Vol.83. P.227-248.

White T.C.R. 2011. The significance of unripe seeds and animal tissues in the protein nutrition of herbivores // Biological Reviews. Vol.86. P.217-224.

White T.C.R. 2013. "Anticipatory" reproduction by small mammals cannot succeed without enhanced maternal access to protein food // New Zealand Journal of Zoology. Vol.40. P.332-336.

Williams C.T., Lane J.E., Humphries M.M., McAdam A.G. \& Boutin S. 2014. Reproductive phenology of a food-hoarding mast-seed consumer: resource- and density-dependent benefits of early breeding in red squirrels // Oecologia. Vol.174. P.777-788. 